\title{
Opätovne k tzv. Monomachovej korune
}

\author{
Tomáš GÁBRIŠs
}

\begin{abstract}
The paper attempts to summarize and re-assess the current status of research on the so-called Crown of Monomachos, an enamel object found in the territory of Slovakia in the second half of the 19th century. The author presents the most recent polemics as to the authenticity, provenience and the original intention and use of the object, being considered by various authors as a diadem, princely or royal crown, or a triumphal arm-ring. The paper argues in favour of the attribution as a female diadem, plausibly belonging to Anastasia of Kievan Rus - given the universal motifs applied mostly in the eastern part of the Byzantine sphere of influence.
\end{abstract}

Keywords: Monomachos, Crown, enamel, Byzantium, Kievan Rus

\section{Úvod}

Vplyvy byzantského umenia na východnú Európu sa dobovo prejavovali jednak prenosom umeleckých štýlov do dielní susedných, či dokonca vzdialenejších krajín, ale aj samotným importom objektov byzantského umenia. Pri importovaných objektoch sa však nezriedka objavujú pochybnosti o okolnostiach ich importu, a dokonca o tom, či šlo o import dobový, alebo až mladší. V súvislosti s územím Slovenska tak možno spomenút' napríklad známy krížik (enkolpion) z Vel'kej Mače, ${ }^{2}$ ktorý bol zobrazený aj na slovenskej desat'korunovej minci. Aj ten je totiž príkladom polemickosti importovaných byzantských umeleckých diel do východnej Európy - v súvislosti s ním sa totiž vyslovujú pochybnosti ako o jeho veku, tak i o jeho pôvodnom účele, a tiež o možnom spô-

\footnotetext{
1 Ďakujem recenzentom príspevku za cenné pripomienky a návrhy na doplnenie, ktoré sú reflektované v konečnom znení predloženého príspevku.

2 Bližšie pozri napr. POLLA, B.: Slovo-dve k ikonografii „mačianskeho náprsného krížika“. In: Zborník Slovenského národnébo múrea, LXXXVIII, 1994, č. 4, s. 169 a nasl.

3 Ibidem.
}

sobe, akým sa na územie Slovenska dostal, ba aj za akých okolností bol nájdený. ${ }^{3}$ Do rovnakej kategórie polemických nálezov z územia Slovenska sa radí i emailový šperk, tzv. Monomachova koruna z Ivanky pri Nitre (dnes v Budapešti, Mad'arské národné múzeum). Pri nej má podl’a niektorých názorov tiež íst' až o mladší import, resp. korist' križiackej výpravy z roku 1204, a teda na územie Slovenska sa vraj dostala iba sekundárne a s odstupom času. ${ }^{4}$ Existuje však aj viacero d’alších teórií o spôsobe, akým sa toto dielo dostalo na územie Slovenska, ktoré zahŕňajú dokonca aj predpoklad, že pôvodne mohlo íst' o královskú korunu z 11. storočia, určenú priamo pre uhorského krála, alebo aspoň o súčast' výbavy či vena jeho manželky. ${ }^{5}$ Rovnako existuje aj väčší počet hypotéz o pôvodnom účele tohto objektu - či totiž vôbec ide o korunu, diadém, alebo o iný druh

4 Túto tézu zastáva viacero súčasných autorov, napr. Holčík a Meško, pozri nižšie. Tiež v prehl'adovej práci VANČO, M.: Od praveku po stredovek. In: BARTOŠOVÁ, Z. a kol.: Umenie na Slovensku: Stručné dejiny obrazov. Bratislava 2007, s. 31.

5 Sumárne tieto hypotézy prezentuje napr. MIHALIK, S.: Problematik der Rekonstruktion der Monomachos-Krone. In: Acta Historiae Artium, IX, 1963, č. 3-4. 
šperku - napríklad výzdobu opasku, oltára, náhrobku, alebo náramenný šperk. Napokon, opomenút' nemožno ani hypotézu, podl'a ktorej ide o falzifikát z 19. storočia. Napriek uplynulým 150 rokom od nálezu tejto pamiatky nie sú zjavne ešte stále všetky otázky okolo tohto artefaktu byzantského umenia uspokojivo zodpovedané. Ba priam naopak, otázniky stále pribúdajú. Hoci pritom na niektoré aspekty problému poukázal na stránkach tohto časopisu naposledy v roku 2013 Petr Balcárek, ${ }^{6}$ k problematike sa na tomto mieste vraciame opätovne, sumarizujúc aktuálny stav poznania do väčšej híbky a zohl’adňujúc aj niektoré novšie názory a tézy.

\section{Tzv. Monomachova koruna - teórie a polemiky}

Jedným z umeleckých remesiel, ktoré v Byzantskej ríši dosahovalo kvality vysokého umenia, bolo i emailérstvo. Konkrétne, od 9. storočia, po odoznení obdobia ikonoklazmu, to bola najmä technika tzv. cloisonné (priehradkového) emailu, ktorá našla široké uplatnenie v Byzancii i mimo Byzancie. Ide o špecifickú smaltovaciu či emailérsku techniku, kde farebná hmota vyplňuje priestory, ktoré vznikli pritavením drôtiku na povrch predmetu. Následne sa tieto predmety vypália, brúsia a leštia. Všeobecne známym príkladom byzantského umenia tohto druhu, zachovaným v západnej Európe, je napríklad tzv. Beresford Hopeov relikviárový kríž z 9. storočia, alebo tiež známa výzdoba oltáru v bazilike sv. Marka v Benátkach, známa ako Pala d'Oro. ${ }^{8}$

Byzantské umenie túto techniku využívalo nielen na výzdobu náboženských artefaktov, ale široké využitie našla i pri svetskej výzdobe, a dokonca aj v rámci výzdoby cisárskych a královských mocen-

\footnotetext{
6 BALCÁREK, P.: Několik poznámek k raněstředověkým destičkám, nalezeným v okolí Nitry. In: Ars, 46, 2013, č. 1, s. 98-102.

Pozri FOLDA, J. - WRAPSON, L. J:: Byzantine Art and Italian Panel Painting. Cambridge 2015, s. 36-37.

8 BETTINI, S.: Venice, the Pala d`Oro, and Constantinople. In: BUCKTON, D. et al.: The Treasury of San Marco Venice. New York 1984, s. 35 a nasl. Dostupné na internete: https:/ / www.metmuseum.org/art/metpublications/The_Treasury_of_San_Marco_Venice (navštívené dňa 19.6. 2021).
}

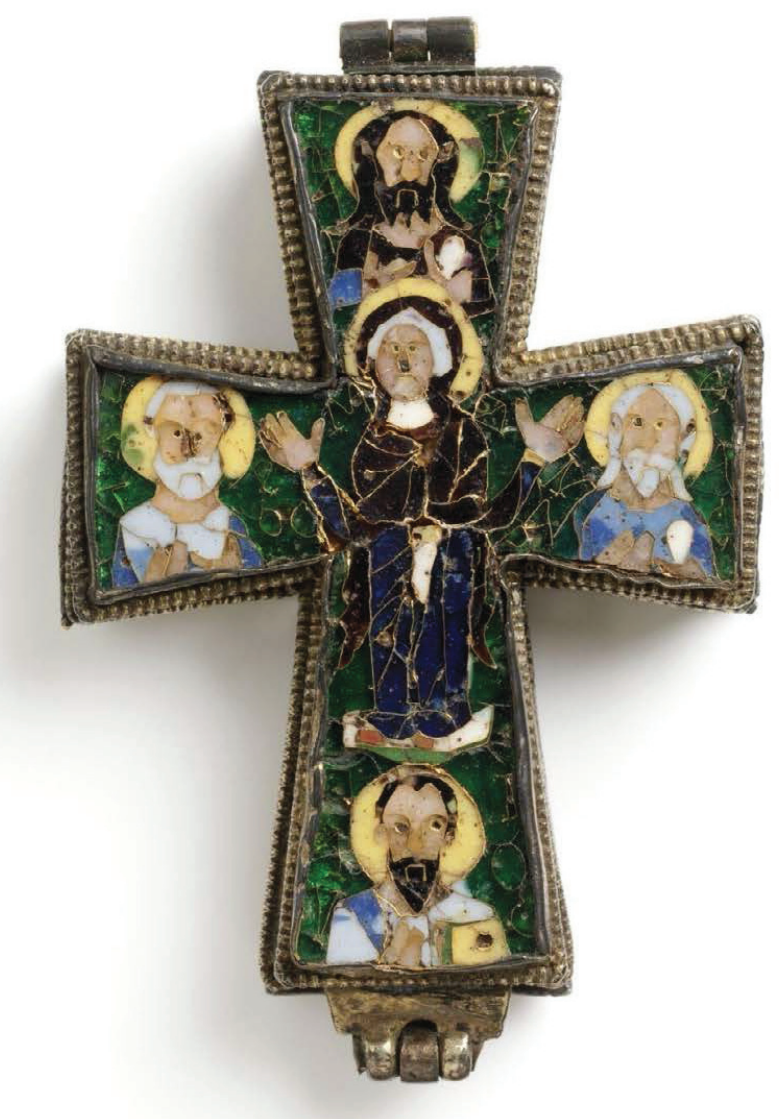

Obr. 1: Beresford Hopeov relikviarový krǐ̌: Foto: https:/ / collections.vam. ac.uk/item/O115274/ beresford-hope-cross-cross-unknown/

ských objektov, akými boli koruny. To je tiež prípad nám osobitne blízkej tzv. svätoštefanskej uhorskej královskej koruny, o ktorej sa niekedy polemizuje ako o diele príbuznom s dlho neznámou Monomachovou korunou. ${ }^{9}$ Ich „príbuznost"“ sa pritom vyvodzuje často práve z toho, že aj uhorská králov-

9 Porovnaj VAJAY, S. de: Corona Regia - Corona Regni Sacra Corona. In: Ungarn-Jahrbuch. Zeitschrift für interdis₹iplinäre Hungarologie, Band 7, 1976. Dostupné na internete: http://epa.oszk.hu/01500/01536/00007/pdf/ UJ_1976_037-064.pdf (navštívené dňa 19. 6. 2021). Z bohatej staršej literatúry možno tiež uviest': BÁRÁNY-OBERSCHALL, M.: Konstantin Monomachos koronája. In: Archeológia Hungarica, 22, 1937, s. 1-48; KÁDÁR, Z.: Quelques observations sur la reconstruction de la couronne de l'empereur Constantin Monomaque. In: Folia Archaeologica, 14, 1964, s. 113-124. 
ská koruna obsahuje emailovú výzdobu, a to ako na svojej staršej, spodnej, gréckej časti (tzv. corona graeca), tak i na svojej mladšej, hornej, latinskej časti (corona latina). ${ }^{10}$

Uhorská svätoštefanská koruna však môže byt' s Monomachovou korunou „príbuzná“ i inými spôsobmi. Obe napríklad obsahujú znázornenie panujúcich vládcov - na Monomachovej to je samotný cisár Konštantín IX. Monomachos, jeho manželka Zoe a jej sestra Teodora, a na svätoštefanskej uhorský král' Gejza I. a cisár Michal VII. Dukas (hoci tento email bol zrejme do koruny vložený až dodatočne $\left.{ }^{11}\right)$. Príbuznost' týchto korún by však mohla mat' i inú, doslova ,pokrvnejšiu“ rovinu - existujú totiž i úvahy, že koruna svätoštefanská má základ v korune král’a Gejzu I. (alebo jeho manželky z Byzancie, král’ovnej Synadene), ktorá bola použitá ako náhrada za stratenú korunu predchádzajúcich Arpádovcov na tróne, Ondreja I. a jeho syna, krála Šalamúna. ${ }^{12}$ Práve touto, stratenou Ondrejovou (a Šalamúnovou) korunou, by vraj mohla byt' Monomachova koruna.

Týmto výpočtom sa však sumár existujúcich teórií o tzv. Monomachovej korune zd'aleka nevyčerpáva. Mihalik približuje d'alšie názory, podl'a ktorých mohlo íst' aj o korunu kyjevskoruského vel'kokniežat'a Vladimíra, alebo korunu, ktorú si od byzantského cisára vyžiadal uhorský král' Samuel Aba a ktorou bol korunovaný v roku 1042, pričom po svojej porážke ju mohol pri úteku bud' zakopat' alebo stratit'. Napokon, mohlo vraj íst' aj o korunu pôvodného následníka trónu po Ondrejovi I., jeho brata Bela, sídliaceho v Nitre. Najrozšírenejšia však bola podl'a Mihalika téza, že ide o korunu krála Ondreja I., ktorú dostal ako dar od byzantského cisára v rokoch 1046 - 1050, a ktorú ukryl na úteku pred svojím bratom Belom. ${ }^{13}$ Mihalik naopak výslovne popieral a neuznával názor, že ide o objekt ulúpený až počas križiackej výpravy v roku $1204 .{ }^{14}$

\footnotetext{
${ }^{10}$ IPOLYI, A.: A Magyar Szent Korona és a koronázási jelvények. története és müleírása. Budapest 1886, s. 166.

${ }^{11}$ Pozri k tomu podrobnejšie RAJKOVÁ, M.: Teórie vzniku svätej koruny Uhorského král'ovstva. In: Historia nova, 7, 2014, s. 67 a nasl. Dostupné na internete: https://fphil.uniba. sk/fileadmin/fif/katedry_pracoviska/ksd/h/Hino7e.pdf (navštívené dňa 19. 6. 2021).
}

${ }^{12}$ VAJAY 1976, c. d. (v pozn. 9), s. 46.

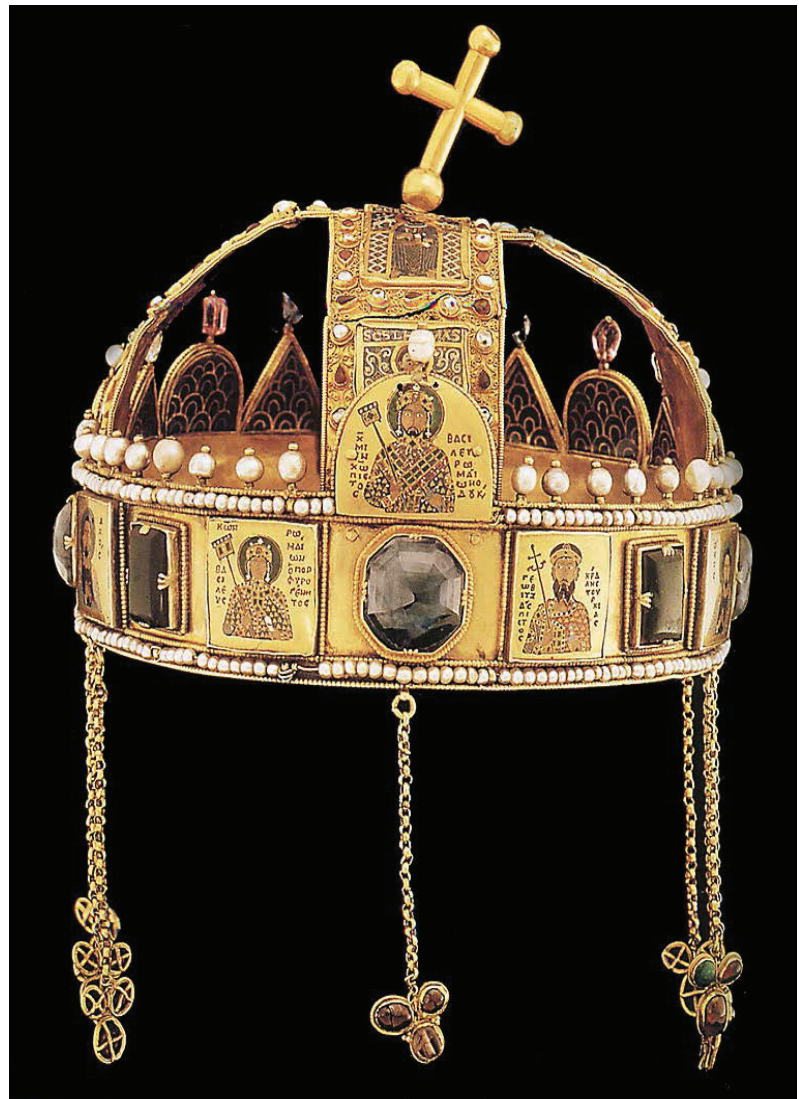

Obr. 2: Uhorská svätoštefanská koruna. Foto: https://commons. wikimedia.org

Staršiu, i Mihalikom podporovanú tézu, že ide o král'ovskú korunu, však dnešná mad'arská historická veda odmieta - a to najmä kvôli jej „ženskému“ tvaru a emailovému zobrazeniu ,ženskej cnosti Pokory“" 15 ale i kvôli predpokladanému použitiu tzv. Egbertovho anglosaského korunovačného rítu, ktorý sa vraj v 11. storočí aplikoval v Uhorsku, a ktorý vyžadoval korunovanie prilbicou a nie otvorenou

${ }^{13}$ MIHALIK 1963, c. d. (v pozn. 5), s. 238.

${ }^{14}$ Ibidem, s. 241.

${ }^{15}$ LADOS, T.: A Monomakhos-korona és I. András koronázás. In: FONS, XXI, 2014, s. 303. Dostupné na internete: https://www.academia.edu/14119809/A_Monomakhos_korona_\%C3\%A9s_I_Andr $\% \mathrm{C} 3 \% \mathrm{~A} 1 \mathrm{~s}$ _koron $\% \mathrm{C} 3 \% \mathrm{~A} 1 \mathrm{z} \% \mathrm{C} 3 \% \mathrm{~A} 1 \mathrm{sa}$ (navštívené dňa 19. 6. 2021). 
korunou. ${ }^{16}$ Stále však pritom zostáva $\mathrm{v}$ hre teória, že mohlo íst' aspoň o byzantský diadém Ondrejovej manželky (Šalamúnovej matky) Anastázie z Kyjevskej Rusi, rodinne spriaznenej s cisárom Konštantínom Monomachom. Túto myšlienku pritom podl'a Kádára navrhol ako prvý Bogyay. ${ }^{17}$ Emailová výzdoba totiž poukazuje na vysokú kvalitu práce, príznačnú osobitne pre cisárske dielne Byzancie 11. storočia. Práve v tomto období predstavovali emailom zdobené diela častý diplomatický dar byzantských cisárov, zasielaný blízkym panovníkom, medzi ktorých sa počítali aj manželskými zväzkami spriaznení kyjevskoruskí vládcovia. ${ }^{18}$

Triezvejšie a kritickejšie sú naopak názory slovenskej spisby, ktorej predstavitelia zväčša hlásajú iba sekundárny nález tohto šperku na území Slovenska, ako korist' križiakov, a pritom popierajú vôbec charakter tohto diela ako koruny, či diadému - ide najmä o názory Štefana Holčíka ${ }^{10}$ a Mareka Meška. ${ }^{20}$ Naopak, český autor Benda, ale aj slovenský byzantológ Alexander Avenarius, mali za to, že skutočne mohlo íst' o súčast' arpádovského královského pokladu, uloženého na hrade $\mathrm{v}$ Nitre, ${ }^{21} \mathrm{i}$ ked' ho nemusíme spájat's konkrétnymi osobami z královskej dynastie.

Napokon, určite treba uviest' i d’alšie kritické názory mimo slovenskej a mad'arskej literatúry, ktoré popierajú, že by šlo o korunu či diadém, a v šperku vidia napríklad výzdobu opasku alebo náramenný šperk, ${ }^{22}$ či dokonca tvrdia, že ide o falzifikát z 19. storočia, s po-

\footnotetext{
${ }^{16}$ Ibidem, s. 313.

${ }^{17}$ KÁDÁR 1964, c. d. (v pozn. 9), s. 123. Ale tiež MORAVCSIK, Gy.: Bizánc és a magyarság. Budapest 1953.

${ }^{18}$ GEORGIEVOVÁ, T.: "Byzantine“" Crowns: between East, West and the Ritual (diplomová práce). Brno 2019, s. 29 a nasl. Uvedené zväzky však spochybňuje KAZHDAN, A.: Rus'-Byzantine Princely Marriages in the Eleventh and Twelfth Centuries. In: Harvard Ukrainian Studies, 12/13, 1988/1989.
}

${ }^{19}$ HOLČÍK, Š. P.: Byzantské emaily z Ivanky pri Nitre. In: Ars, 18,1984 , č. 1 , s. 35-50.

${ }^{20}$ MEŠKO, M.: Boli byzantské emailové platničky z Ivanky pri Nitre súčast'ou koruny? In: Slovensko a európsky jubovýchod. Medzikulturne vat'aby a kontexty. Eds.: AVENARIUS, A. ŠEVČÍKOVÁ, Z.: Bratislava 1999, s. 402-411.

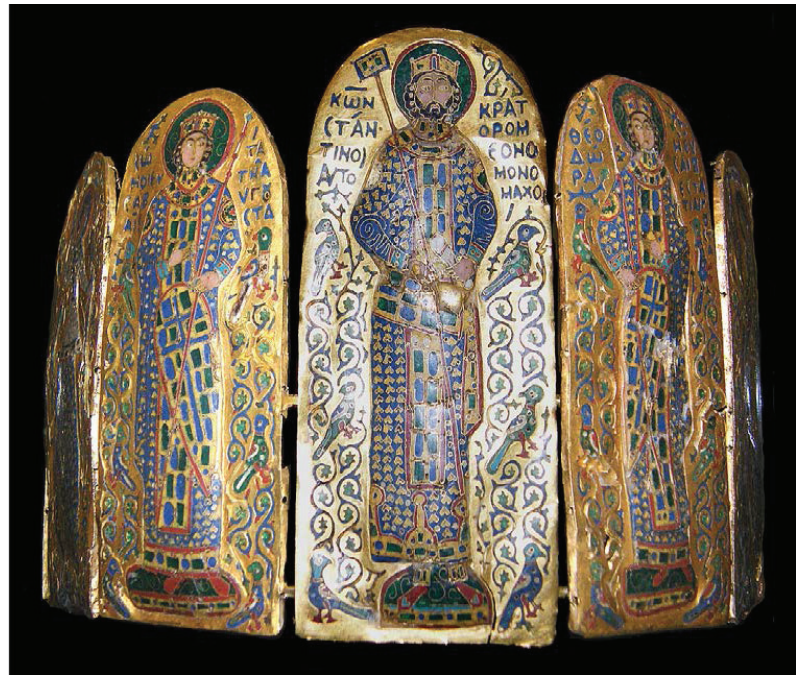

Obr. 3: Monomachova koruna. Celný pobl'ad. Foto: https:/ / commons. wikimedia.org

ukazom na viaceré výrobné nedostatky diela a tvrdené neštandardnosti $\mathrm{v}$ zobrazení postáv. ${ }^{23}$ Tieto pochybnosti usilovne vyvracia najmä mad'arská literatúra. ${ }^{24}$

$\mathrm{Na}$ tomto mieste si dávame za ciel' sumárne priblížit' jednotlivé argumenty, ktoré sa používajú $\mathrm{v}$ prospech a $\mathrm{v}$ neprospech naznačených alternatív, pričom $\mathrm{k}$ nim zaujmeme naše vlastné stanovisko hoci ani to vzhl’adom na súčasný stav poznania určite nebude definitívnym.

${ }^{21}$ BENDA, K.: Byzantské a raně křest’anské památky v Československu. In: LASSUS, J.: Raně krèrt'anské a byzantské uméní. Praha 1971, s. 184; AVENARIUS, A.: Byzantská kultúra v slovanskom prostredí v VI. - XII. storočc. K problému recepcie a transformácie. Bratislava 1992. Sumarizované podl'a BALCÁREK 2013, c. d. (v pozn. 5), s. 98-102.

${ }^{22}$ DAWSON, T.: The Monomachos Crown - Towards a Resolution. Athens 2009. Dostupné na internete: https:// ejournals.epublishing.ekt.gr/index.php/bz/article/viewFile/3162/3023 (navštívené dňa 19. 6. 2021).

${ }^{23}$ OIKONOMIDÈS, N.: La couronne dite de Constantin Monomaque. In: Travaux et Mémoires, XII, 1994, s. 241-262.

${ }^{24}$ KISS, E.: Új eredmények a Monomachus-korona kutatásában? In: Folia Archeologica, XLVI, 1997, s. 125-162; KISS, E.: The State of Research into the Monomachos Crown and Some Further Thoughts. In: Perceptions of Byzantium and Its Neighbours (843-1261). Ed.: PEVNY, O. Z. New York 2000. 


\section{Monomachova koruna - argumenty pre a proti}

Tzv. Monomachova koruna, uložená v Mad’arskom národnom múzeu v Budapešti, je objekt zložený zo siedmich zlatých platničiek, bohato zdobených emailom. Na centrálnych troch platničkách nájdeme menovatel'a tejto „koruny“ - byzantského cisára Konštantína IX. Monomacha (najväčšia pozdĺžna platnička), jeho manželku, cisárovnú Zoe, a jej sestru a spoluvládkyňu Teodoru. Zvyšné štyri platničky sa delia na dve s tancujúcimi ženskými postavami a dve (najmenšie) so statickými alegorickými postavami cností, symbolizujúce Pravdu a Pokoru. Ich vel'kosti a poradie nedávno zhrnul Balcárek ${ }^{25}$ - korunu tak tvorí zl'ava doprava platnička s cnost'ou Pokory o vel'kosti $87 \times 42 \mathrm{~mm}$, tanečnica obrátená heraldicky dolava o vel'kosti platničky $100 \times 45 \mathrm{~mm}$, cisárovná Zoe na platničke o $105 \times 48 \mathrm{~mm}$, cisár Konštantín Monomach na platničke o vel'kosti $115 \times 50 \mathrm{~mm}$, cisárovná Teodora na platničke s vel'kost'ou $107 \times 48$ mm, tanečnica obrátená opät' heraldicky dol’ava na platničke o $98 \times 45 \mathrm{~mm}$, a napokon platnička s cnost'ou Pravdy (podl'a Balcárka Spravodlivosti) s vel'kost'ou $87 \times 42 \mathrm{~mm}$.

Celková dížka všetkých platničiek po ich spojení dosahuje iba $320 \mathrm{~mm}$, čo niektorých autorov vedie práve preto $\mathrm{k}$ teóriám, že kvôli krátkej dížke celého súboru nejde o korunu ani diadém. Iných to zase naopak vedie $k$ hladaniu d'alších stratených platničiek, ktoré vidia napríklad v platničke tanečnice uloženej v depozite Victoria and Albert Museum v Londýne ${ }^{26}$ (ktorá je navyše vhodne obrátená heraldicky doprava).

Ich teóriám nahrávajú aj nejasné okolnosti nálezu tejto „koruny“. Budapeštianske platničky boli nájdené v roku 1860 v katastrálnom území obce Ivanka pri Nitre, kde ich náhodne pri práci na poli objavil miestny rol'ník. Viacerými transakciami sa dostali do vlastníctva národného múzea $v$ Budapešti, ${ }^{27}$ avšak

\footnotetext{
${ }^{25}$ BALCÁREK 2013, c. d. (v pozn. 6), s. 98-102.

${ }^{26}$ Pod sign. M.325-1921. Porovnaj CAMPBELL, M.: An Introduction to Medieval Enamels. London 1983.

${ }^{27}$ Podrobne v: MIHALIK 1963, c. d. (v pozn. 5), s. 199-204.
}

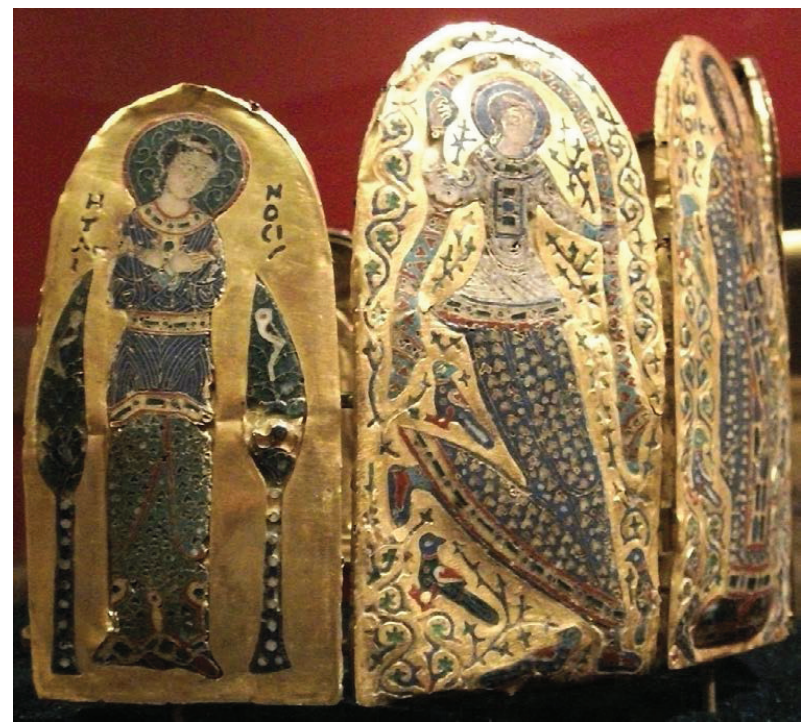

Obr. 4: Monomachova koruna. Bočný poblad. Foto: https:// commons. wikimedia.org

práve skutočnost', že boli predávané vo viacerých transakciách, vedie niektorých autorov $\mathrm{k}$ tomu, že v skutočnosti mohlo byt' súčast'ou nálezu i viac platničiek, ktoré sa môžu nachádzat' v iných zbierkach (vrátane londýnskej tanečnice).

Koruna je aj preto dlhodobo predmetom záujmu nielen čo do jej pôvodu a originálneho účelu, ale i vizuálnej podoby zachytených objektov, techniky zobrazenia, a tiež techniky spojenia jednotlivých platničiek, ktoré vykazujú nerovnomerne rozložené otvory, neumožňujúce ich pravidelné spojenie retiazkou či obručou. ${ }^{28}$ Henry Maguire v roku 1997 navrhol vysvetlenie, podl'a ktorého tieto nerovnomernosti možno objasnit' tým, že platničky boli našité na látke, a to bud' na opasku alebo na diadémovej čelenke. ${ }^{29}$ Obdobné riešenie pritom vraj možno nájst' na zobrazení Teodory, manželky cisára Teofila z prvej polovice 9 . storočia, v kronike

\footnotetext{
${ }^{28}$ Ibidem, s. 513-514.

${ }^{29}$ MAGUIRE, H.: The Glory of Byzantium: Art and Culture of the Middle Byzantine Era, A.D. 843-1261. New York 1997. Dostupné na internete: https:/ / books.google.co.uk/books?id=Caqa12aj55wC \& pg=PA210\# $\mathrm{v}=$ onepage $\& \mathrm{q} \& \mathrm{f}=$ false (navštívené dňa 19. 6. 2021).
} 


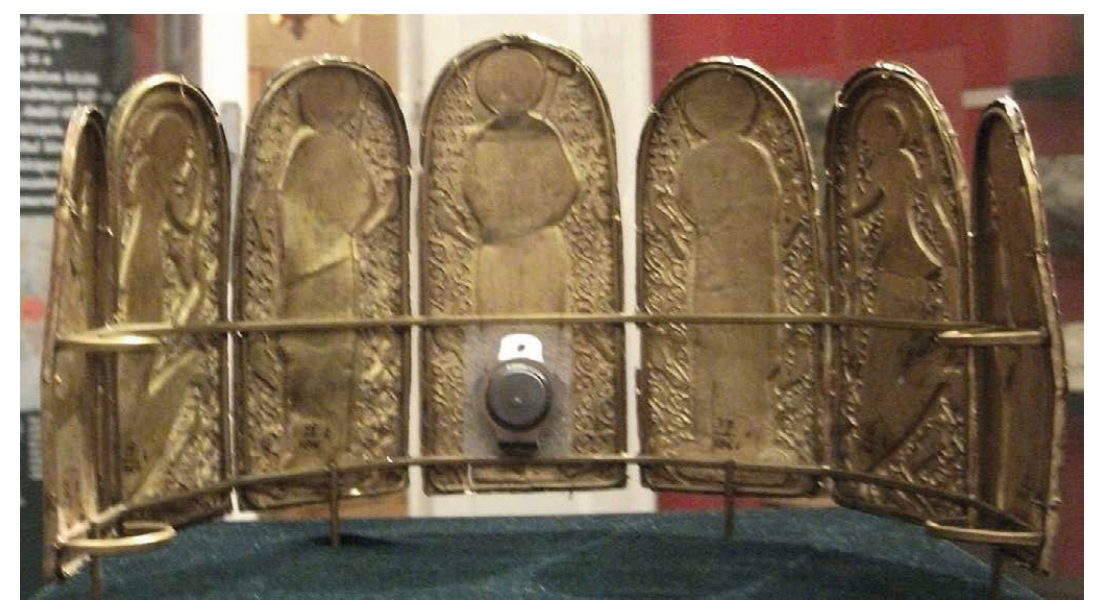

Obr. 5: Monomachova koruna. Pobl'ad zozadu. Foto: https:// commons.wikimedia.org

Jána Skylitzesa, ${ }^{30}$ hoci toto zobrazenie je pomerne nezretel'ným a neurčitým. ${ }^{31}$

Mohlo by to však legitimizovat' hypotézu, že pri tejto „korune“ ide skutočne o ženský diadém, napríklad práve Ondrejovej manželky, uhorskej královnej Anastázie, pochádzajúcej z Kyjevskej Rusi. Tá bola prostredníctvom svojho brata zošvagrená $\mathrm{s}$ byzantskou cisárskou rodinou, a to dokonca priamo s Konštantínom IX. Monomachom, s ktorým je táto koruna, či diadém, úzko spojená.

Centrálna platnička koruny (diadému) totiž zachytáva cisára Konštantína IX. Monomacha, v plnom cisárskom splendore. V spodnej časti sú zachytené výhonky révy a šest' farebných vtákov. Po jeho pravici a l'avici sú umiestnené platničky zobrazujúce cisárovnú Zoe a jej sestru Teodoru, a od nich d'alej platničky s tanečnicami. Obe cisárovné sú na platničkách Monomachovej koruny dozdobené podobne ako cisár vínnou révou s vtákmi. Tieto motívy obsahujú aj platničky s tanečnicami. Obe tanečnice pritom majú jednu nohu exoticky ohnutú (zakopnutú) dozadu v naznačení pohybu (tanca), pričom

\footnotetext{
${ }^{30}$ GEORGIEVOVÁ 2019, c. d. (v pozn. 18), s. 27.

${ }^{31}$ Ide o kódex BNE MSS Graecus Vitr. 26-2 Codex Græcus Matritensis Ioannis Skyllitzes, fol 50va. Pozri bližšie TSAMAKDA, V.: The Illustrated Chronicle of Ioannes Skylitzes. Leiden 2002.
}

jedna z tanečníc si drží nad hlavou závoj. Napokon, dve okrajové platničky zachytávajú už zmienené dve cnosti Pravdu a Pokoru, dozdobené cyprusmi.

Nápisy na platničke s cisárom obsahujú jeho označenie $v$ gréčtine ako „Konštantín Monomachos, autokrator Rimanov".32 Platnička so Zoe obsahuje grécky nápis „ZOE, NAJZBOŽNEJŠIA AUGUSTA“333 a platnička s Teodorou nápis ,TEODORA, NAJZBOŽNEJŠIA AUGUSTA “. ${ }^{34}$ Nápisy síce obsahujú ortografické chyby, tie sa však objavujú aj na emailovej podobizni Ireny Komneny na už zmienenom oltári Pala d'Oro v Benátkach, a nemusí to preto automaticky vyvolávat' pochybnosti o pravosti diela, ani o jeho cisárskej proveniencii. Aj zobrazenia cisárovien so štítmi majú svoje obdoby v Teodorinom žaltári z roku 1066, kde sú podobne ženské postavy zobrazené so štítmi s krížom. ${ }^{35}$ Práve tým sa argumentuje proti pochybnostiam o pravosti tzv. Monomachovej koruny a o jej cisárskom pôvode.

Viacero úvah sa v minulosti spájalo aj so smerovaním pohl'adu jednotlivých zachytených postáv. Kým totiž cisár hladí nal’avo, Zoe po jeho pravici

\section{${ }^{32}$ KSNCTANTINOC AYTOKPATO POMEON O MONO- MAXOC.}

${ }^{33}$ ZGDE OI EYCAIBAICTATH AYГOYCTA.

${ }^{34} \Theta$ E0 $\Delta$ GOPA H EYCAIBECTATI AYTOYCTA.

${ }^{35}$ MAGUIRE 1997, c. d. (v pozn. 29). 


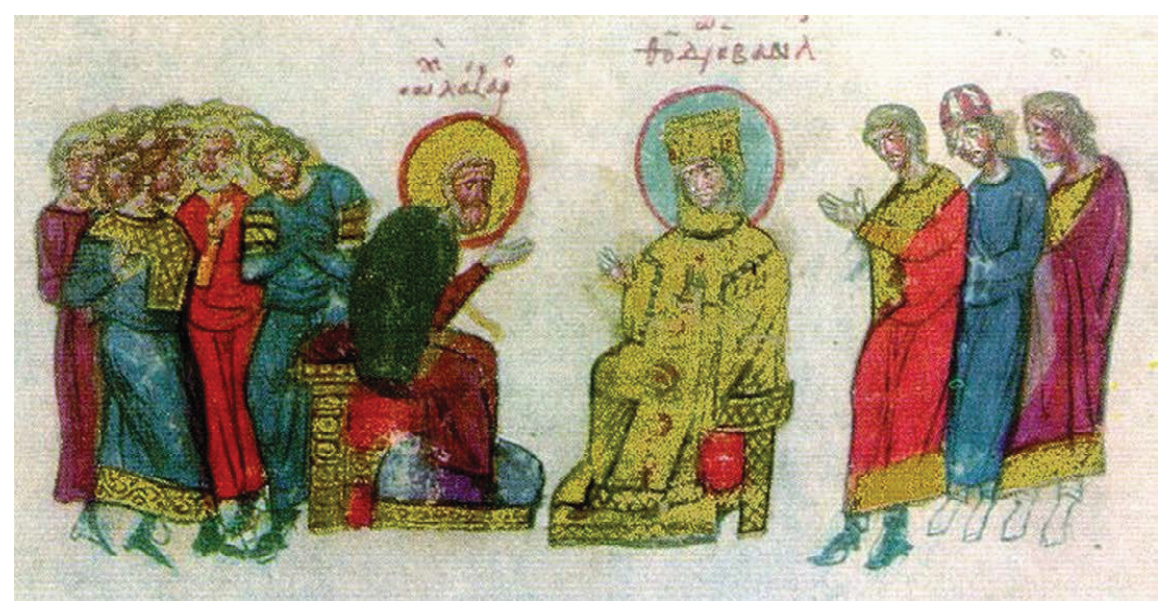

Obr. 6: Cisárovná Teodora v Skylitzesovej kronike (fol. 50va). Foto: https:/ / commons.wikimedia.org

tiež hl'adí nal'avo a Teodora po jeho l'avici hl'adí napravo. Cisárovné teda akoby hladeli na cisára, ale on hl'adí na Teodoru a nie na Zoe, svoju manželku. Vysvetl'ovalo sa to predpokladom, že vedl'a cisára sa mala nachádzat' ešte jedna platnička, zachytávajúca Krista, na ktorého mal cisár hl'adiet'. Ide však iba o hypotézu - aj iné reprezentácie cisárskych manželov preukazujú, že smerovanie pohladu nemuselo hrat' $\mathrm{v}$ dobových zobrazeniach žiadnu významnejšiu rolu. Dôkazom má byt' miniatúra zo Sinaja, kde sa Zoe a Konštantín tiež pozerajú rôznymi smermi. ${ }^{36}$

Otázniky však vyvstávajú aj v súvislosti so zobrazením tanečníc, ktorých výjav je v spojení s cisárskym majestátom zriedkavým. Pritom sa tiež poukazuje na to, že obe sú orientované heraldicky dol’ava, čo narúša ideálnu symetriu koruny či diadému. Navyše, zobrazené sú spôsobom, ktorý má bližšie k sásanovským alebo moslimským tradíciám, ked’že zjavne vykazujú isté orientálne prvky. Cecily Hilsdale pritom nedávno vyslovila pomerne presvedčivý názor, že exotické prvky tanečníc naznačujú vzájomnost' a zdiel’ané „univerzálne“ predstavy medzi panovník-

\footnotetext{
${ }^{36}$ Ide o manuskript z kláštora Sv. Kataríny na vrchu Sinaj, so sign. Ms. 364, fol. 3r. Pozri MAGUIRE 1997, c. d. (v pozn. 29), s. 210.

${ }^{37}$ HILSDALE, C. J.: The Social Life Of The Byzantine Gift: The Royal Crown Of Hungary Re-Invented. In: Art History, 31, 2008, s. 611.
}

mi východnej časti Európy a západnej a strednej Ázie o luxusných dekoráciách, ${ }^{37}$ čo by mohlo naznačovat' práve určenie tohto šperku ako daru pre spriazneného panovníka na pomedzi východnej Európy a Ázie, resp. pre jeho manželku alebo dcéru.

„Tradičnejšie“" sa však tieto tanečnice identifikujú bud' s motívmi dcér Jeruzalema, tancujúcimi na počest' starozákonného Dávida po jeho vít’azstve nad Goliášom, alebo naopak „,netradičnejšie“ s motívom Konštantínovej konkubíny Sklerainy. ${ }^{38}$ Kvôli ich svätožiaram sa však uvažuje, že nemôže íst' o Konštantínovu konkubínu, ale skôr pôjde o d'alšie personifikácie zobrazených cností, o chór grácií, či prípadne o personifikáciu vít’azstva. ${ }^{39}$

Napokon, aj pokial' ide o zachytenie cností Pravdy a Pokory, platí tu tiež opatrné upozornenie, že kým Pravda bola v spojení s cisárom zachytávaná pravidelne, Pokora je ojedinelým obrazovým spojením, hoci rétoricky sa v dobových textoch s cisárom spájala častejšie. ${ }^{40}$ Etele Kiss poukazuje i na konkrétne dobové teologické dielo, ktoré možno s takýmto zobrazením spájat' - dielo sv. Izáka z Ninive (Izák Sýrsky), ktorý je autorom súboru homílií, prelože-

\footnotetext{
${ }^{38}$ Tak napr. MIHALIK 1963, c. d. (v pozn. 5).

${ }^{39}$ GEORGIEVOVÁ 2019, c. d. (v pozn. 18), s. 29 a nasl.

${ }^{40}$ MAGUIRE 1997, c. d. (v pozn. 29).
} 
ných v 9. storočí do gréčtiny, v ktorých sa má tento obraz - Pokory a Pravdy - objavovat'. ${ }^{41}$

Vtáky a florálne motívy na väčšine platničiek pritom tiež majú súvisiet' práve s literárnymi a rečníckymi figúrami používanými v dobovej Byzancii, ktoré cisára spájali s budovaním záhrady cností (ako metafory pre rísu), v ktorej je sám jedným z vtákov, prípadne jedným zo stromov. Podobné motívy sa však spájali aj s cisárovnami a členkami cisárskej rodiny (rovnako ako idea ,ženskej cnosti Pokory“). Aj preto môže byt' nejasné, či tieto platničky a celý diadém či koruna mali byt' nosené mužskou alebo ženskou postavou, a teda komu bola vlastne tzv. Monomachova koruna určená. Aj preto je však stále akceptovatel'nou teória, že mohlo íst' práve o manželku Ondreja I., Anastáziu, pôvodom z Kyjevskej Rusi, ${ }^{42}$ čo by vysvetl'ovalo aj niektoré vyššie uvedené exotické prvky a niektoré nezrovnalosti cisárskej ikonografie, ktoré by sa zrejme nevyskytovali na diadéme určenom pre samotného príslušníka cisárskej dynastie.

Viaceré naznačené neštandardnosti zobrazenia pritom v 90. rokoch 20. storočia viedli historika Nicolasa Oikonomidesa k radikálnemu záveru, podl'a ktorého výrobné nedostatky tohto diela, ako je napríklad už spomenutá nerovnomernost' otvorov na upevnenie, ale tiež gramatické nedostatky v gréckych nápisoch na jednotlivých platničkách, a tiež niektoré neobvyklosti $\mathrm{v}$ zobrazení postáv, treba považovat' za dôkazy toho, že v skutočnosti ide pri tzv. Monomachovej korune o falzifikát z 19. storočia. ${ }^{43}$

Konkrétny výpočet Oikonomidesových argumentov za falošnost' koruny a na druhej strane vyvrátenie týchto argumentov prináša Etele Kiss. ${ }^{44}$ Ked' totiž Oikonomides kritizuje ortografické chyby na nápisoch, použitie samotného pojmu „autokrator“ bez „basileus“, či poukazuje na tvar koruny a pendílií, Kiss protiargumentuje tým, že oddelené používanie

\footnotetext{
${ }^{41}$ KISS 1997, c. d. (v pozn. 24), s. 156. Bližšie pozri ALFEJEV, I.: Izák Syrský a jeho duchouní odkaz: Červený Kostelec 2010.

${ }^{42}$ GEORGIEVOVÁ 2019, c. d. (v pozn. 18), s. 35.

43 OIKONOMIDÈS, N.: La couronne dite de Constantin Monomaque. In: Travaux et Mémoires, XII, 1994, s. 241-262.

${ }^{44}$ KISS 2000, c. d. (v pozn. 24), s. 68 a nasl.
}

prívlastkov cisárskej hodnosti sa vyskytovalo bežne, a aj tvar koruny v obdobnej forme sa nachádza na zobrazení cisárovnej na ikone v kláštore sv. Kataríny Alexandrijskej na hore Sinaj, pričom rovnaký tvar pendílií nájdeme aj na diadéme zo Sachnovky a na zobrazení biblického krála Šalamúna na mozaike Anastasis v Hosios Loukas. Napokon, aj tvar štítu (thorakionu) na platničkách zachytávajúcich podobu cisárovien sa podobá na medailóny z gruzínskeho Khakhuli. Proti výčitke o nesprávnom umiestnení thorakionu tiež Kiss uvádza, že thorakion sa nosí v rôznych zobrazeniach na rôznych stranách. ${ }^{45}$

Iní autori, napríklad už zmienený Maguire, Oikonomidesove výčitky podobne odmietajú s poukazom na to, že prítomnost' rovnakých ortografických a iných nedostatkov sa preukázala aj v iných dielach, o ktorých pravosti a byzantskom cisárskom pôvode nemožno pochybovat'.

Ak d'alej Oikonomides spochybňuje zobrazené vtáky a cyprusy, či zobrazenie Pokory v súvislosti s cisárom, alebo vyplnenie pozadia platničiek v akomsi „horror vacui“, to všetko sa podla Kissa prejavuje práve $\mathrm{v}$ tvorbe prítomnej v okrajových oblastiach Byzancie, pričom sám poukazuje na diela vytvorené v kaukazských dielňach. Napokon, zobrazenie Pravdy a Pokory ako dvoch cností, presvedčivo vysvetl'uje pojednaním o práve týchto dvoch cnostiach v už spomenutom dobovom homiletickom diele sv. Izáka z Ninive (Sýrskeho). ${ }^{46}$

Oikonimides však tiež spochybňuje podobu a postoj tanečníc, pričom poukazuje na ich zarážajúcu podobnost' s inými dielami, z ktorých mali byt' tanečnice skopírované - ako príklad mu slúži innsbrucká artukidská platňa/misa ${ }^{47}$ Podobnost' však ešte automaticky neznamená, že tanečnice museli byt' skopírované falšovatel'om z 19. storočia. Niektoré príklady na takéto tanečnice totiž ponúka aj E. Kiss. ${ }^{48}$ Tanečnice pritom vysvetl'uje obrazom z Dávidovho života, kde poukazuje na

\footnotetext{
${ }^{45}$ Ibidem.

${ }^{46}$ Ibidem.

${ }^{47}$ Porovnaj: http://beyondborders-medievalblog.blogspot. com/2012/09/the-artuqid-plate.html (navštívené dňa 19. 6. 2021). Bližšie pozri STEPPAN, T.: The Artuqid Bowl: Medieval Enamel Art Between East and West. München 1995.

${ }^{48}$ KISS 1997, c. d. (v pozn. 24), 148-149.
} 


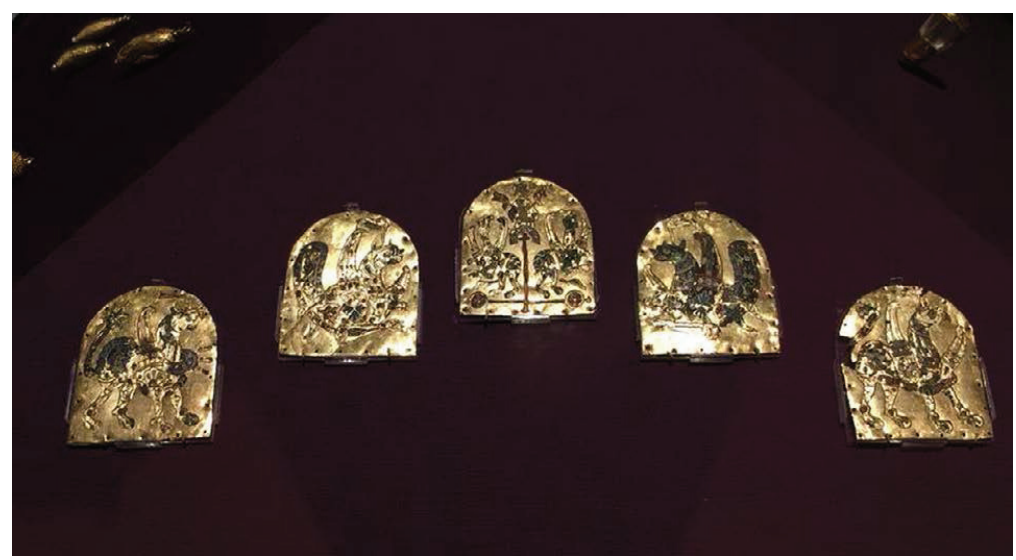

Obr. 7: Diadém z Preslavy. Foto: https:// cmc.byzart.eu/items/show/121049/

tanec Miriam - ako symbol vít'azstva. ${ }^{49}$ Doplnit' tu však možno i Mihalikov argument o tom, že zobrazenia tanečníc $\mathrm{v}$ takejto tanečnej polohe mohli byt' rozšíreným motívom, ktorý sa vyrábal vo viacerých dielňach, čo by vysvetl'ovalo aj odlišné chemické zloženie a sfarbenie londýnskej platničky s tanečnicou (za predpokladu, že by nešlo o falzifikát z prelomu 19. a 20. storočia).

Kiss tiež navyše opätovne poukazuje i na to, že v Skylitzesovej kronike má Teodora cylindrickú pokrývku hlavy s obdobnými platničkami (fol. 50va), pripomínajúcimi obdobu Monomachovej koruny. ${ }^{50}$ Obdobne, podl'a Cecily Hilsdale je dokladom o pravosti koruny tiež vernost' zobrazenia cisárskych regálií na Monomachovej korune, ktoré zodpovedá rozdielom medzi mužskými a ženskými korunami presne ako to vidíme na iných zobrazeniach korún Monomacha, cisárovnej Zoe a jej sestry, cisárovnej Teodory. ${ }^{51}$ Dokazujú to opätovne napríklad emaily z oltára Khakhuli z Gruzínska. ${ }^{52}$

Proti tomu, že koruna je neskorší falzifikát, však napokon môžu hovorit' aj niektoré archeologické súvislosti z územia Slovenska - totiž, v roku 1914 sa v Ivanke pri Nitre našla aj minca Konštantína Mo-

\footnotetext{
${ }^{49}$ Ibidem, s. 155.

${ }^{50}$ Ibidem, s. 131.

${ }^{51}$ HILSDALE 2008, c. d. (v pozn. 37), s. 614.

${ }^{52} \mathrm{~K}$ nemu pozri napr. KOTSIS, K.: Mothers of the Empire: Empresses Zoe and Theodora on a Byzantine Medallion
}

nomacha a v Čifároch sa dokonca našlo až 7 d'alších byzantských mincí. To všetko vo vzájomnej súvislosti naznačuje, že skutočne sa v týchto oblastiach mohol nachádzat' dobový poklad, ${ }^{53}$ ktorého súčast'ou mohla byt' i tzv. Monomachova koruna, resp. diadém.

\section{Diadém alebo náramenný šperk?}

Po rokoch polemík o pravosti Monomachovej koruny predstavil Timothy Dawson v roku 2009 svoju úplne novú teóriu, ktorá mala byt' konečným potvrdením pravosti, ale i radikálne odlišným vysvetlením účelu, ako aj iných nejasností spojených s Monomachovou korunou. ${ }^{54}$ Konkrétne, Dawson má za to, že v skutočnosti išlo o mužský ozdobný šperk, ktorý niesol na svojom ramene pri slávnosti triumfu cisársky vojvodca, eunuch Pergamen. Obdobné šperky nosené pri triumfoch má potvrdzovat' portrét Bazila II. v žaltári v knižnici Sv. Marka v Benátkach. ${ }^{55}$

$\mathrm{Na}$ tomto mieste si však dovolíme vyslovit' pochybnost' o takomto riešení. Jednak totiž podl'a nás možno pochybovat' o tom, že by sa takýto šperk zachoval práve z ojedinelej udalosti triumfu jedného z velitel'ov, ktorého majetok bol navyše následne

Cycle. In: Medieval Feminist Forum: A Journal of Gender and Sexuality, 48, 2012, č. 1, s. 5-96.

${ }^{53}$ KISS 2000, c. d. (v pozn. 24), s. 64.

${ }^{54}$ DAWSON 2009, c. d. (v pozn. 22).

${ }^{55}$ Ibidem, s. 187. Biblioteca Nazionale Marciana, Cod. Gr. 17., fol. 1. 


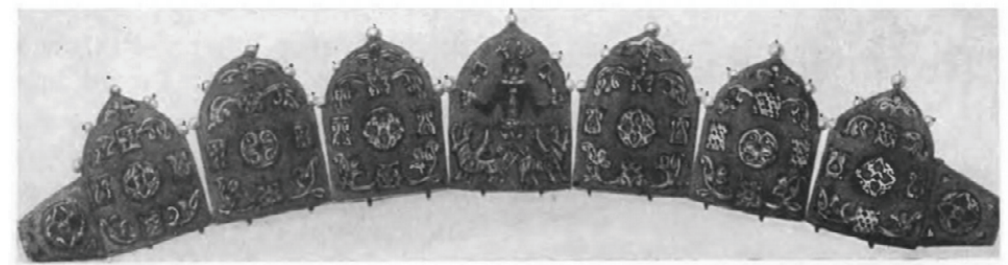

Obr. 8: Diadém zo Sachnovky (nájdený v roku 1900 pri Kyjeve). Foto: https: / rezansky.com/ the-revealing-world-of-medieval-kievan-rus-applied-art /

cisárom skonfiškovaný, ale pochybnost' máme aj ohl'adom jeho predpokladaného umiestnenia na ramene ruky. Ak totiž jednotlivé platničky majú zjavne vertikálne členenie s tým, že sa predpokladá ich zvislé umiestnenie tak, aby boli zretel'né jednotlivé postavy a nápisy, možno mat' pochybnost' o teórii umiestnenia na ramene, ktoré sa môže zdvíhat' aj pripažovat'. Takéto umiestnenie navyše tiež zrejme neumožňuje ocenit' divákom jednotlivé nápisy a zobrazenia zachytené na tomto diele. Nejasné by potom tiež bolo to, akým spôsobom sa toto dielo dostalo do Ivanky pri Nitre - skutočne by sme tak mohli počítat' jedine s alternatívou koristi v rámci križiackej výpravy z roku 1204.

Naproti Dawsonovi však viacerí autori ${ }^{56}$ podl'a nás správne a presvedčivo poukazujú na skutočnost', že obdobné objekty - emailové platničky - nachádzame vo východnej Európe napríklad aj v Bulharsku a na Ukrajine, pričom napospol šlo o diadémy nosené na hlave, kde mohla práca umelca skutočne vyniknút', a kde zároveň zostáva zachovaná vertikalita postáv aj pri motorike nositel'a diadému.

Za všetky tu možno priblížit' diadém z bulharskej Preslavy. ${ }^{57} \mathrm{~V}$ rámci tzv. pokladu z Preslavy boli v roku 1978 pri práci rol'níkov na poli objavené viaceré bulharsko-byzantské šperky, ktoré však boli kvôli použitiu t’ažkých mechanizmov doslova rozmetané po poli, poškodené, čiastočne zničené, a kvôli neistote ohl'adom ich pôvodnej lokalizácie tiež i t'ažko kunsthistoricky spojitel'né a zaraditel'né.

Čast' tohto pokladu predstavuje pät' emailových platničiek, ktoré majú predstavovat' tzv. diadém

\footnotetext{
${ }^{56}$ Tak napr. i už citovaný Maguire.

${ }^{57}$ TOTEV, T.: The Preslav Treasure. Shumen 1993. Dostupné na internete: https:/ /archive.org/stream/PreslavTreasure/bulgaria_preslav-treasure_djvu.txt (navštívené dňa 19. 6. 2021).
}

z Preslavy. Opät' pritom ide o platničky s cloisonné (priehradkovým) emailom, ktoré sú v hornej časti oblúkovo zakončené, podobne ako platničky Monomachovej koruny. Podobne ako v prípade Monomachovej koruny tiež nie je zrejmý konečný počet platničiek, ktoré mali predstavovat' celý diadém. Vel'kost' dochovaných častí je však v porovnaní s centrálnymi platničkami Monomachovej koruny menšia - dosahujú výšku $5,4 \mathrm{~cm}$ a šírku $4,4 \mathrm{~cm}$, a hmotnost'ou sa líšia v rozsahu od 5,8 do 6,6 gramu. Rozdiel $\mathrm{v}$ hmotnosti vyplýva $\mathrm{z}$ rozsahu zachovania emailu na jednotlivých platničkách a z rozdielne náročnej výzdoby. Rovnako ako Monomachova koruna, platničky majú tiež otvory na bočných a spodných stranách. Spolu však po spojení dosahujú dížku iba $22 \mathrm{~cm}$, čo je ešte menej než má Monomachova koruna, ktorej zachované časti spolu dosahujú dížku vyše $30 \mathrm{~cm}$. Predpokladá sa však, že na konci diadému z Preslavy mohli byt' na oboch stranách d'alšie dve platničky, ktoré by mohli mat' podobu asi ako posledné platničky diadému zo Sachnovky z Kyjeva, a ktoré mali slúžit' práve na zapnutie diadému za pomoci osobitného mechanizmu, prípadne retiazky alebo šatky. Celkovo tak vraj mohol mat' Preslavský diadém asi $35-36 \mathrm{~cm},{ }^{58}$ čím sa už podobá Monomachovej korune.

Diadém z Preslavy však vykazuje s Monomachovou korunou aj d'alšiu - hoci nepriamu - spojitost'. $\mathrm{Na}$ svojom centrálnom paneli síce nezachytáva aktuálneho byzantského panovníka, ale predsa zobrazuje panovníka - Alexandra Macedónskeho a jeho vstúpenie na nebesá, čo je príbeh, ktorý sa

Novšie INKOVA, M.: Аиадемата от Преславското съкровище. In: Bulgaria Mediaevalis, 9, 2018, s. 53-92.

${ }^{58}$ TOTEV 1993, c. d. (v pozn. 57), s. 21-22. 
v byzantských podmienkach začína šírit' najmä $\mathrm{v} 5$. a 6. storočí. Tento príbeh bol populárny aj na území dnešného Bulharska, kde sa dokonca v 10. storočí objavujú aj jeho slovanské varianty. Takýto symbol pritom mohol mat' nielen dekoratívnu funkciu, ale napríklad i funkciu ochranného amuletu, alebo prípadne i symbolicky funkciu uznania byzantských či bulharsko-macedónskych panovníckych tradícií. Zjavne postrehnutel'né sú však tiež i použité orientálne prvky - mytologické zvieracie figúry, gryfovia a iné postavy. Tie sa pritom podl'a bulharských kunsthistorikov úplne bežne vyskytujú $\mathrm{v}$ byzantskom umení práve v období vlády macedónskej dynastie v Byzantskej ríši 9. až 12. storočia, a to pod priamym vplyvom perzského a moslimského umenia. ${ }^{59}$ Do rovnakej kategórie vplyvov sa pritom nepochybne môžu radit' aj tanečnice na Monomachovej korune.

Napokon, obdobné motívy môžeme identifikovat' aj v prípade už zmieneného kyjevskoruského diadému zo Sachnovky, ${ }^{60}$ ktorý však popri centrálnej panovníckej postave a mytologických zvieratách obsahuje na zvyšných platničkách diadému skôr abstraktnejšie geometrické motívy vlnoviek a esoviek, aké boli príznačné osobitne pre západoeurópske normansko-keltské kultúrne vplyvy - ktoré v podobe kyjevskoruských Varjagov a dynastie Rurikovcov tiež nemožno vylúčit'.

V prípade poskytnutých príkladov diadémov vytvorených zrejme podla byzantského vzoru je podl'a nášho názoru podobnost's tzv. Monomachovou korunou viac ako zrejmá. Preto by tiež podl’a nás mohla byt' aj teória Monomachovej koruny ako diadému patriaceho kyjevskoruskej manželke Ondreja I. pravdepodobnejšou než teória o náramennom šperku cisárskeho vojvodcu, ktorý by sa na územie Slovenska dostal po križiackej výprave z roku 1204. $\mathrm{V}$ prípade akceptovania kyjevskoruskej teórie sa totiž táto koruna (diadém) mohla v Ivanke ocitnút' celkom logicky - najmä v dôsledku vojenskej výpravy krála Šalamúna, Ondrejovho a Anastáziinho syna, ktorý útočil na Nitru v roku $1074 .{ }^{61}$ Pri tejto výprave mohol diadém predstavovat' súčast' jeho pokladu,

\footnotetext{
${ }^{59}$ Ibidem, s. 27-28.

${ }^{60}$ DMYTRENKO N. The reconstruction of a diadem from Sakhnivka village of Cherkasy region and the question about its attribution. In: Ukrainian Academy of Arts, 25, 2016, s. 289-302.
}

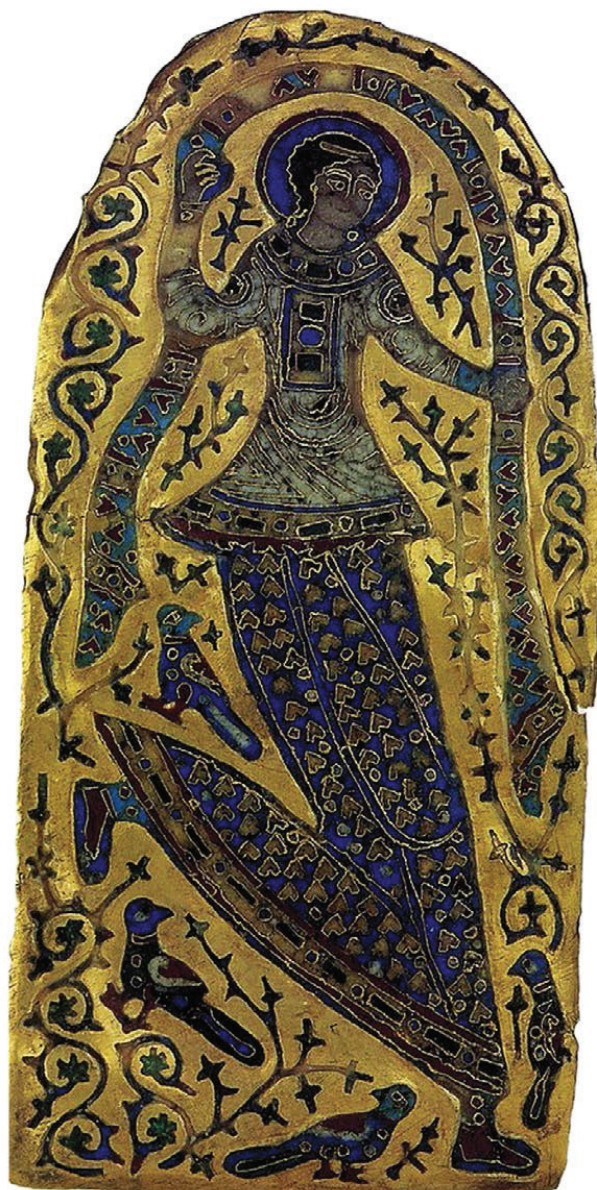

Obr. 9: Tanénnica z. Monomachovej koruny. Foto: https:// commons. wikimedia.org

zdroja financií, alebo ozdobu členky jeho výpravy. Proti teórii, že by šlo o jeho vlastnú královskú korunu hovoria už spomenuté ,ženské“ znaky tohto diadému, ale tiež predpokladaný korunovačný rítus, uprednostňujúci prilbu pred korunou. ${ }^{62}$

Akceptovatel'nou je však tiež teória, že Šalamún mohol tento diadém získat' aj od Judity, svojej manželky, dcéry cisára Henricha III., ktorý tiež disponoval početnými diplomatickými darmi od byzantského cisára. ${ }^{63}$

${ }^{61}$ GEORGIEVOVÁ 2019, c. d. (v pozn. 18), s. 34.

${ }^{62}$ LADOS 2014, c. d. (v pozn. 15), s. 313.

${ }^{63}$ KISS 2000, c. d. (v pozn. 24), s. 65. 


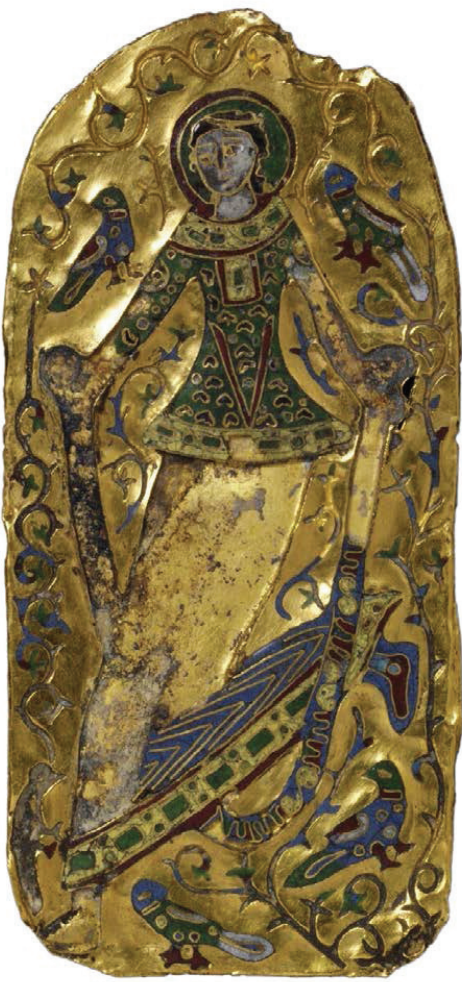

Obr. 10: Tanéñica ₹ Victoria and Albert Museum. Foto: bttps:// collections.vam.ac.uk/item/0103209/plaque-unknown/

Napokon, ešte stále však v hre zostáva i možnost' arpádovského pokladu uloženého v Nitre a ukrytého pred nebezpečenstvom, hoci i v neskoršej dobe než v 11. storočí.

Osobne však vzhl'adom na doteraz uvedené považujeme za skutočne pravdepodobnejšiu tézu o určení tohto diadému ako ženského šperku, ktorý mohol byt' byzantským darom pre spriaznenú panovnícku rodinu - avšak nie priamo pre panovnícku nevestu ako príslušníčku byzantskej cisárskej rodiny, ktorej diadém by zrejme bol ozdobený motívmi bližšími oficiálnej cisárskej ideológii. Použité „exotické motívy" mohli vyhovovat' skôr východnejšej panov-

${ }^{64}$ LADOS 2014, c. d. (v pozn. 15), s. 292. Vychádza z DEÉR, J.: A magyarok Szent Koronája. Budapest-MáriabesenyőGödöllő 2005, s. 149-150.

${ }^{65}$ Dostupné na internete: https:/ / collections.vam.ac.uk/item/ O103209/plaque-unknown/ (navštívené dňa 19. 6. 2021).

${ }^{66}$ Toto tvrdenie sa v dostupných zdrojoch spája zásadne s konštatovaním, že londýnske analýzy preukázali pravost' Mono- níckej dynastii, čím sa opät' vraciame k Ondrejovej manželke, Anastázii.

\section{Londýnska tanečnica a tanečnica z Ukrajiny}

$\mathrm{Na}$ záver by sme ešte radi poukázali na otázne vzt'ahy tzv. Monomachovej koruny s inými artefaktmi umiestnenými v Londýne a na Ukrajine. Už vyššie sme uviedli, že vel'mi podobná platnička s tanečnicou, dokonca s obdobnou florálnou výzdobou spojenou s vtákmi, je umiestnená aj v londýnskom Victoria and Albert Museum, pričom táto je $\mathrm{v}$ katalógu daného múzea označená ako pravdepodobný falzifikát. Že ide o falzifikát, verí aj Lados, vychádzajúc z Deéra. ${ }^{64}$ Práve pri tomto objekte nám však na webovej stránke Victoria and Albert Museum chýbajú podrobnejšie informácie a dôvody považovania tohto diela za falzifikát ${ }^{65}$ - či totiž ide iba o záver vyplývajúci $z$ podobnosti s Monomachovou korunou, Oikonomidesom považovanou za falzifikát, alebo či sa na artefakte uskladnenom v depozitári múzea vykonali $i$ iné skúšky a overovania pravosti.

O existencii tohto objektu $\mathrm{v}$ Londýne pritom historici umenia preukázatel'ne vedeli počas celého 20. storočia, a preto sa niekedy stretneme aj s konštatovaním, že Monomachova koruna pôvodne pozostávala z ôsmich platničiek, pričom tá londýnska vraj má byt' ôsmou, ktorá bola zaslaná do Londýna na expertízne posúdenie. ${ }^{66}$ Uvedené však vyvracajú údaje, podl'a ktorých bola táto platnička nadobudnutá v 20. rokoch od anglického zberatel'a, ktorý ju vraj zakúpil v Budapešti. Podl’a Balcárka ju totiž predal H. R. Wilson v roku 1921 vtedajšiemu múzeu v South Kensingtone (dnes Victoria and Albert Museum). H. R. Wilson ju údajne kúpil ešte pred rokom 1909 u neznámeho budapeštianskeho starožitníka.

Podl'a Balcárka je pritom všeobecne akceptovaným predpoklad, že ide o falzum z dielne Fabergého, podobne ako približne d'alších 150 kusov petrohradskej tzv. Botkinovej kolekcie. ${ }^{67}$ Proti pravosti

machovej koruny. Tak napr. BEŇOVÁ, J.: Monomachovu korunku našiel oráč v poli. In: SME. Dostupné na internete: https://cestovanie.sme.sk/c/706017/monomachovu-korunku-nasiel-orac-v-poli.html (navštívené dňa 19. 6. 2021).

${ }^{67}$ BALCÁREK 2013, c. d. (v pozn. 6), s. 98-102. Pozri tiež BUCKTON, D.: Byzantine enamels in the twentieth century. In: Ed. JEFFREYS, E.: Byzantine Style, Religion and Civilization. In Honour of Sir Steven Runciman, Cambridge 2006, s. 25-90. 
londýnskej tanečnice hovorí aj Zomboryho analýza zloženia zlatých platničiek, ktorá v roku 1936 preukázala, že londýnska platnička je takmer z čistého zlata, pričom $99,5 \%$ rýdzost' zlata bola v 11 . storočí asi iba sotva dosiahnutel'ná. ${ }^{68}$

Z Botkinovej zbierky pritom preukázatel'ne pochádza i takmer totožná (ale menšia) platnička s tanečnicou, ktorá sa nachádza v zbierke Platar ukrajinských vlastníkov S. a M. Platonových. Napriek rozdielnej vel'kosti (londýnska má $105 \times$ 49,5 $\mathrm{mm}$, kyjevská $70 \times 29 \mathrm{~mm}$ ), sú pritom zarážajúco podobné, a to dokonca vrátane poškodení emailu na suknici tanečníc. To je podl’a Balcárka dostatočne podozrivé na to, aby sa i londýnska tanečnica mala považovat' za falzifikát z dielne Fabergého. ${ }^{69}$ My už k tomu iba zopakujme zmienenú rýdzost' zlata londýnskej tanečnice $(99,5 \%)$.

Navyše je tiež už na prvý pohlad zrejmým, že londýnska ôsma (a ani kyjevská deviata) platnička nezodpovedajú predpokladanému rozmiestneniu jednotlivých platničiek Monomachovej koruny, a ani vel'kost'ou nezodpovedajú predpokladanému pokračovaniu tvaru koruny. Navyše, príliš podobný motív tanečnice by sme na korune so striedajúcimi sa motívmi zrejme neočakávali - iba ak by boli tanečnice vskutku až štyri, po dve otočené dol'ava a dve doprava.

Mihalik tu síce ako riešenie ponúka alternatívu, že koruna obsahovala ešte d'alšiu, tretiu a štvrtú tanečnicu, predpokladal však, že pôjde o tanečnicu rovnakej hmotnosti a hrúbky ako londýnska tanečnica, ktorá by zároveň bola orientovaná rovnako ako londýnska tanečnica (heraldicky doprava), aby tak obe dopĺńali dve budapeštianske platničky, orientované rovnakým smerom (heraldicky dol'ava). ${ }^{70} \mathrm{~V}$ prípade ukrajinskej tanečnice však jej vel'kost' nielenže nezodpovedá vel'kosti londýnskej tanečnice, ale nezodpovedá ani predpokladanej vel'kosti d'alších hypotetických častí Monomachovej koruny, resp. diadému.

$\mathrm{Aj}$ z tohto pohladu sa preto prikláňame $\mathrm{k}$ stanovisku, že tieto tanečnice nepatrili k Monomachovmu diadému, hoci mohli pochádzat' z tej istej dielne, v ktorej vznikla tzv. Monomachova koruna.

${ }^{68}$ LADOS 2014, c. d. (v pozn. 15), s. 296. ZOMBORY, L.: The Gold Content of the Plaques of the Monomachos Crown. In: BÁRÁNYNÉ-OBERSCHALL, M.: The Crown of the Emperor Constantine Monomachos. Budapest 1937, s. 40.

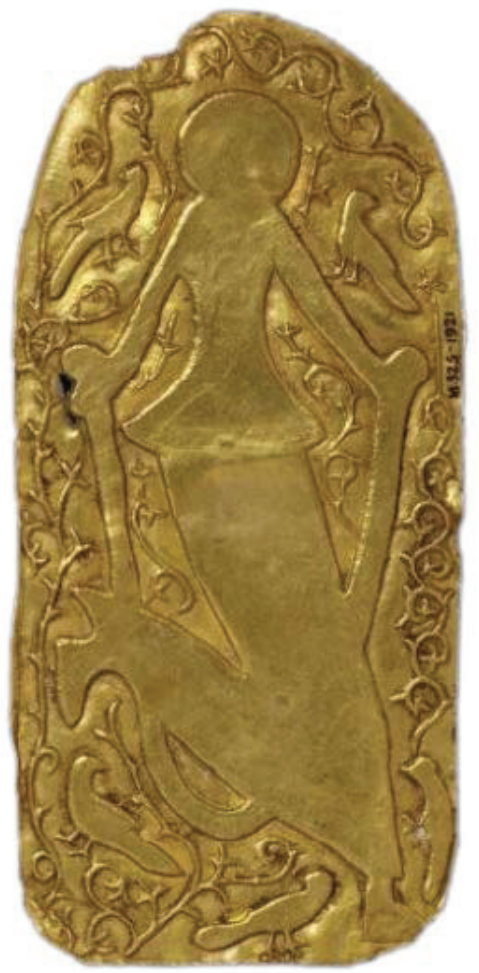

Obr. 11: Poblad na platničku s tanečnicou z. Victoria and Albert Museum zozadu. Foto: https:/ / collections.vam.ac.uk/ item/O103209/ plaque-unknown $/$ ?carousel-image $=2006$ AC4794

K pravosti londýnskej a kyjevskej tanečnice, resp. ich určeniu ako falzifikátu z dielne Fabergého, sa tu definitívne nevyjadrujeme.

\section{Záver}

Diadém zo Sachnovky, ale i bulharský preslavský diadém, nám naznačujú všeobecnú obl'úbenost' tohto typu ozdoby medzi vel'možmi a panovníkmi patriacimi do byzantského kultúrneho okruhu. Avšak i ked' tzv. Monomachova koruna do vel'kej miery pripomína diadémy z Preslavy a Sachnovky, je tiež na prvý pohl’ad zrejmý rozdiel v kvalite tých to prác, ako i v použitých námetoch. Kým bulharské a kyjevskoruské diadémy naznačujú skôr mytologické a silné

\footnotetext{
69 BALCÁREK 2013, c. d. (v pozn. 6), s. 98-102.

${ }^{70}$ MIHALIK 1963, c. d. (v pozn. 5)
} 
orientálne vplyvy, najmä iránske, sásanovské a keltsko-normanské, Monomachova koruna sa naopak do vel'kej miery pridŕža oficiálnej cisárskej ikonografie. Výnimku tu predstavujú asi iba čiastočne orientálne vplyvy pri zobrazení tanečníc. Obdobné tancujúce postavy so závojmi v rukách a so "zakopnutou“ nohou pri tanci však nachádzame aj v ilumináciách byzantských rukopisov, a preto nemusí íst' až o taký exotický a výnimočný prvok. Je však tiež pravdou, že ak by šlo o produkt určený pre samotnú cisársku rodinu, dielo by bolo zrejme vyzdobené motívmi príznačnejšími pre cisársky dvor.

$\mathrm{Na}$ druhej strane, zachytenie cisárskej rodiny na takomto diadéme namiesto mytologických prvkov, avšak s istými exotickými prvkami, pritom môže výrečne poukazovat' na skutočne špecifického adresáta a nositel'a (resp. adresátku a nositel'ku), ktorý bol predsa len viac identifikovaný s oficiálnou byzantskou teóriou moci, a ktorý mal priame spojenie s cisárskou rodinou, hoci nie postavenie rovnocenné s cisárom. To by potom ladilo i so zachytením Pokory ako cnosti „podriadenosti“ a ,poslušnosti“ na jednej z platničiek. Zároveň však ale zrejme nemalo íst' o nositel'a alebo nositel'ku, ktorí by boli priamo príslušníkmi byzantskej cisárskej rodiny. Súhlasíme totiž s Hilsdaleovou, podla ktorej koruny, ktoré sú darom pre nevestu z Byzancie, resp. súčast'ou jej výbavy, zvyčajne nepouživajú „exotické“ dekorácie, ktoré Hilsdaleová nazýva „univerzálnymi“ - vystihujúcimi nadnárodné, resp. východoeurópske a ázijské predstavy o panovníckej reprezentácii.

Na základe všetkého uvedeného tak zrejme možno konštatovat', že v prípade tzv. Monomachovej koruny vskutku mohlo íst' o diadém určený práve pre kyjevskoruskú manželku Ondreja I. s potenciálne byzantským príbuzenstvom, čo sa nám javí ako najplauzibilnejšia hypotéza spomedzi všetkých uvedených a- aj vzhl'adom na „exotickost" motívov, príznačnú skôr pre východné dielne. Konvenuje tomu aj súčasný stav poznania, podl’a ktorého si Ondrej bral Anastáziu za svoju druhú manželku v roku 1049, v čase, kedy všetky tri postavy zachytené na diadéme boli ešte nažive, a diadém tak mohol slúžit' ako Anastáziin svadobný dar. ${ }^{71}$

Naopak, oprávnene možno podl'a nášho názoru pochybovat' o tom, že mohlo íst' o náramenný šperk. Nižší počet platničiek diadému totiž treba podla nášho názoru vysvetlit' namiesto menšieho obvodu ramena skôr iným spôsobom upevnenia diadému či už našitím na pokrývku hlavy, alebo použitím látky alebo inej techniky kovového spojenia, ako to vidíme napríklad na diadéme zo Sachnovky. Tieto alternatívy si však vyžadujú ešte d'alšie porovnanie so zachovanými dobovými zobrazeniami a hmotnými pamiatkami, ktoré jediné nám môžu naznačit' väčšiu pravdepodobnost' niektorej z uvedených hypotéz.

\footnotetext{
${ }^{71}$ LADOS 2014, c. d. (v pozn. 15), s. 304-305.
} 


\title{
Again to the so-called Monomach Crown
}

\author{
Résumé
}

Although the so-called Monomach crown resembles diadems from Preslav and Sakhnivka, there is also an obvious difference in the quality of these works, as well as in the themes applied. While the Bulgarian and Kievan diadems suggest rather mythological and strong oriental influences, especially Iranian and Sasanian, but also some Celtic-Normanic influences, on the other hand, the Monomach crown largely adheres to official imperial iconography. Some exception here is only the oriental influences in the depiction of female dancers. However, similar dancing figures with veils in their hands can be found in the illuminations of Byzantine manuscripts, and therefore these should not be considered an exceptional element. However, it is also true that should the product be intended for the imperial family itself, it would most probably be decorated with motifs more characteristic of the imperial court. On the other hand, the image of the imperial family on the diadem together with some exotic elements may in fact point to a truly specific addressee and bearer of the product, who must have been acquainted with official Byzantine theory of power. and who possibly had a direct connection with the imperial family, though not a position equivalent to the emperor. This conclusion would be in harmony with the image of Humility as a virtue of ,,subordination" and „obedience" on one of the plates of the crown. Still, one can agree here with C. Hilsdale that a bridal gift for a bride from Byzantine imperial dynasty would not not use „exotic" decorations, which Hilsdale calls „universal“" - depicting transnational, respectively. Eastern European and Asian notions of sovereign representation. However, the use of such motifs would certainly be acceptable if it was a diadem or tiara intended for a Kievan princess with possible Byzantine kinship. Attribution of the diadem known as Monomachos crown to Anastasia, the wife of Hungarian King Andrew I., thus seems to be the most plausible hypothesis of all the existing theories - also with regard to the „exotic" motifs characteristic of eastern workplaces of Byzantine sphere of cultural influence. This is also confirmed by the current state of knowledge, according to which Andrew married Anastasia as his second wife in 1049, at a time when all three imperial figures depicted on the diadem (Monomachos, Zoe and Theodora) were still alive, and the diadem could thus indeed serve as Anastasia's wedding gift.

Prof. JUDr. PhDr. Tomáš Gábriš, PhD., LLM, MA

Ústav štátu a práva Slovenská akadémia vied

Klemensova 19

SK-813 64 Bratislava e-mail: gabris.tomas@gmail.com 